\title{
Quantitative analysis of lactose and lactulose in urine by high performance liquid chromatography for determination of intestinal lactase activity
}

\author{
Nani Dharmasetiawani, ${ }^{*}$ Herman Suryadi, ${ }^{*}$ Agus Firmansyah,
}

\begin{abstract}
Abstrak
Penetapan aktivitas laktase usus secara langsung dilakukan dengan mengukur laktase di epitel usus halus. Cara ini merupakan cara yang invasif dan secara etis tidak dapat dilakukan pada bayi sehat. Secara tidak langsung, penetapan aktivitas laktase, yang dinyatakan sebagai rasio ekskresi dan konsumsi laktosa dan laktulosa, memerlukan waktu 30 jam observasi di rumah sakit. Tujuan penelitian ini ialah mencari metoda penetapan aktivitas laktase yang tidak invasif dan tidak memerlukan waktu observasi yang lama. Bayi diberikan laktosa dan laktulosa sekaligus setelah 2 jam puasa, kemudian kadar laktosa dan laktulosa dalam urin diukur dengan Kromatografi Cair Kinerja Tinggi. Aktivitas laktase dinyatakan dengan rasio ekskresi urin konsumsi laktulosa dan laktosa. Penelitian ini membuktikan bahwa cara pemberian laktosa dan laktulosa satu kali setelah puasa 2 jam dapat dipakai untuk penetapan aktivitas laktase dan bayi hanya perlu pengawasan selama 7 jam. (Med J Indones 2003; 12: 8-12)
\end{abstract}

\begin{abstract}
Determination of intestinal lactase activity is directly done by measuring its activity in intestinal epithelium. This is an invasive method and ethically can not be done in healthy infants. Indirectly, determination of lactase activity, stated as excretion and ingestion ratio of lactose and lactulose, needs 30 hours hospitalized infants. The aim of this study was to look for a method for determination of lactase activity which is not invasive and not necessary hospitalized. Using this method lactose and lactulose were given as a single oral load after 2 hours fasting. Urine were collected for 5 hours starting from consuming sugar solution and then lactose and lactulose concentration in the urine were measured by High Performance Liquid Chromatography. The results showed single oral load of lactose and lactulose can be used for determination of lactase activity in infant and the infants were observed only for 7 hours. (Med J Indones 2003; 12: 8-12)
\end{abstract}

Keywords: Lactase activity, Lactulose, Lactose, High Performance Liquid Chromatography

Infants need nutritious food in order to grow and developed accordingly. Food digestion in gastrointestinal tract system needs enzymes. Enzymes development depends on postnatal adaptation which is intermediate metabolism to milk, changing in food needs, and tolerance to variety of food according to the infant maturation degree. Inadequate gastrointestinal enzymes during neonatal period caused maldigestion in newborn infants, especially less than 1 month, hence there are less nutritions that being absorbed. ${ }^{1,2}$ Newborn infants ability in carbohydrate and triglyceride digestion are lower compare to the protein

\footnotetext{
* Department of Child Health, Budi Kemuliaan Maternity Hospital, Jakarta, Indonesia

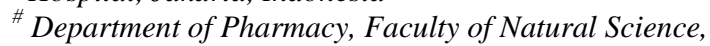
University of Indonesia, Jakarta, Indonesia

$\$$ Department of Child Health, Medical Faculty, University of Indonesia, Jakarta, Indonesia
}

digestion. The main carbohydrate in milk for newborn infants is lactose and lactase activity is still relatively low leading to limitation in lactose digestion., ${ }^{3,4}$ Lactose in intestinal brush border are being hydrolised by lactase to glucose and galactose, which will be absorbed by small intestine. ${ }^{6,7}$ The amount of hydrolised lactose depends on lactase activity. Some of unhydrolised lactose will be absorbed passively by intestinal epithelium and excreted in urine. ${ }^{8,9}$

Determination of lactase activity directly was done by measuring lactase in intestinal epithelium. ${ }^{10}$ This is an invasive method and ethically can not be done in healthy infants.

Some former researcher have done the study in intestinal permeability and lactase activity in infants. ${ }^{9,11,12,13,14}$ Intestinal permeability examination performed by given lactulose and manitol with the ratio 7:1 or 5:1 which are given with drink. After 24 
hours, when a steady state of sugar input and output had been reached, urine are then collected during 5 hours and stored in $-20^{\circ} \mathrm{C}$ before analysis. Urine will be analysed with Gas Liquid Chromatography ${ }^{9,11,12}$ or High Performance Liquid Chromatography. ${ }^{13,14}$ Determination of lactase activity needs lactose and lactulose to be given. Lactase activity is stated as the excretion ratio of lactose and lactulose to the ingestion of lactose and lactulose. ${ }^{9}$ In infant aged 1 month, lactulose could not always being detected in urine when the test was performed by the steady state method, since intestinal permeability was already reduced. ${ }^{13}$ In that case, a single oral load method are given minimum 2 hours after the last drink and then urine are collected for 5 hours. ${ }^{12,13}$

There are only a few studies to measure lactase activity $^{9,14}$ and unfortunetely can not be reproduced in our laboratory. The aim of this study is to establish method of determination of lactase activity by modification of previous studies.

\section{METHODS}

Urine specimen of 4 infants aged 7 days (2 infants) and 30 days ( 2 infants) born at Budi Kemuliaan Maternity Hospital, in January 2002, were examined. Sugar solution of lactose and lactulose were given orally in three different ways. One infant was given 2 $\mathrm{g}$ lactose in $30 \mathrm{ml}$ milk formula and $1 \mathrm{~g}$ lactulose in 6 $\mathrm{ml}$ water; another infant was given $200 \mathrm{mg}$ lactose and $1 \mathrm{~g}$ lactulose in $10 \mathrm{ml}$ water, and another 2 infants were given $1 \mathrm{~g}$ lactose and $1 \mathrm{~g}$ lactulose in $10 \mathrm{ml}$ water.

Infants were given sugar solution after 2 hours fasting. Then after 30 minutes, infants were given water ad libitum, and after 30 minutes more were allowed to drink their own milk. Urine were collected during 5 hours starting from consuming sugar solution and stored at temperature of $-20^{\circ} \mathrm{C}$ until analysis.

One $\mathrm{ml}$ of urine specimens in the test tubes were extracted by acetonitril and chloroform (1:1:1). Lactose and lactulose in urine were determined upon previous study by HPLC. ${ }^{14}$ One $\mathrm{ml}$ of urine sample were spun in a $1,5 \mathrm{ml}$ microcentrifuge tube at a rate of $3000 \mathrm{rpm}$ for 5 minutes, then filtered through a 0,45 $\mu \mathrm{m}$ filter. A $20 \mu \mathrm{l}$ of the filtered sample was injected onto Metachem ${ }^{\circledR}$ Metacarb Ca Plus $(300 \mathrm{~mm} \mathrm{x} \mathrm{7,8}$ $\mathrm{mm}$ ) cation exchange column, protected with a precolumn, at a flowrate of $0,4 \mathrm{ml} /$ minute, and at temperature of $60^{\circ} \mathrm{C}$. The column effluent was monitored with refractive index detector (Shimadzu RID 6 A). The analytical conditions were calibrated with lactose and lactulose as standard. The calibration curve for lactose was determined with concentration of $12,04 \mu \mathrm{g} / \mathrm{ml}, 50,57 \mu \mathrm{g} / \mathrm{ml}, 101,36 \mu \mathrm{g} / \mathrm{ml}, 198,66$ $\mu \mathrm{g} / \mathrm{ml}, 397,32 \mu \mathrm{g} / \mathrm{ml}, 794,64 \mu \mathrm{g} / \mathrm{ml}, 999,32 \mu \mathrm{g} / \mathrm{ml}$, $1204,0 \mu \mathrm{g} / \mathrm{ml}, 1605,0 \mu \mathrm{g} / \mathrm{ml}, 2410,0 \mu \mathrm{g} / \mathrm{ml}$, and the equition of calibration curve was $\mathrm{y}=-4394,9+$ $326,1 \mathrm{x}$ with regression of 0,9998 . The calibration curve for lactulose was determined with concentration of $10,01 \mu \mathrm{g} / \mathrm{ml}, 54,29 \mu \mathrm{g} / \mathrm{ml}, 108,58 \mu \mathrm{g} / \mathrm{ml}, 199,06$ $\mu \mathrm{g} / \mathrm{ml}, 410,76 \mu \mathrm{g} / \mathrm{ml}, 796,22 \mu \mathrm{g} / \mathrm{ml}, 1001,31 \mu \mathrm{g} / \mathrm{ml}$, $1206,4 \mu \mathrm{g} / \mathrm{ml}, 1603,0 \mu \mathrm{g} / \mathrm{ml}, 2430,0 \mu \mathrm{g} / \mathrm{ml}$, and the equition of calibration curve was $\mathrm{y}=-5806,7+$ $347,5 x$ with regression of 0,9992 .

Lactose and lactulose concentration were determined by comparing the area of lactose and lactulose in chromatogram to the standard. The excretion ratio of lactulose and lactose in urine was then calculated. Lactase activity was stated by the ratio of excretion and ingestion of lactulose and lactose.

\section{RESULTS}

Lactase activity, stated as lactulosa and lactose excretion and ingestion ratio, was determined in the urine of 4 healthy infants. Two different ages, which is 7 and 30 days, were chosen to know whether the marker was excreted, so the method can be performed in infants. Infants characteristic given single oral load method were shown in Table 1.

Table 1. Infants characteristic given single oral load method

\begin{tabular}{ccccc}
\hline Case & $\begin{array}{c}\text { Age } \\
\text { (days) }\end{array}$ & $\begin{array}{c}\text { Gestational } \\
\text { age } \\
\text { (weeks) }\end{array}$ & $\begin{array}{c}\text { Birth } \\
\text { weight } \\
\text { (grams) }\end{array}$ & $\begin{array}{c}\text { Weight at the } \\
\text { time of examination } \\
\text { (grams) }\end{array}$ \\
\hline Case 1 & 7 & 38 & 3000 & 3000 \\
Case 2 & 7 & 37 & 2500 & 2600 \\
Case 3 & 30 & 36 & 2400 & 3800 \\
Case 4 & 30 & 38 & 2600 & 3500 \\
\hline
\end{tabular}

Table 2 shows the result of determination of lactulose and lactose in urine of the infant. In case 1 , lactulose and lactose Ingestion Ratio (IR) was 0,5. Urinary lactulose concentration was $108,2 \mu \mathrm{g} / \mathrm{ml}$ and lactose concentration was $4167,5 \mu \mathrm{g} / \mathrm{ml}$, Excretion Ratio (ER) was 0,02 . Ratio of excretion and ingestion (E/I Ratio) of lactulose and lactose was 0,04 (Figure 1). In case 2, IR was 5 and ER was 6,53. E/I Ratio of lactulose and lactose was 1,31 (Figure 2). In case 3 and 4, IR was 1. ER in case 3 was 1,38, E/I Ratio was 1,38 (Figure 3). ER in case 4 was 0,48, E/I Ratio was 0,49 (Figure 4). 
Table 2 . The results of lactase activity determination

\begin{tabular}{|c|c|c|c|c|c|c|c|}
\hline \multirow[b]{2}{*}{ Case } & \multicolumn{3}{|c|}{ Ingestion } & \multicolumn{3}{|c|}{ Excretion } & \multirow[b]{2}{*}{$\begin{array}{c}\text { E/I } \\
\text { RATIO }\end{array}$} \\
\hline & $\begin{array}{c}\text { Lactulose } \\
\text { g/10mL }\end{array}$ & $\begin{array}{l}\text { Lactose } \\
\text { g/10 mL }\end{array}$ & IR & $\begin{array}{c}\text { Lactulose } \\
\mu \mathrm{g} / \mathrm{mL}\end{array}$ & $\begin{array}{l}\text { Lactose } \\
\mu \mathrm{g} / \mathrm{mL}\end{array}$ & ER & \\
\hline Case 1 & 0,3 & $0,6^{*}$ & 0,5 & 108,2 & 4167,5 & 0,02 & 0,04 \\
\hline Case 2 & 1 & 0,2 & 5 & 1250,6 & 191,3 & 6,53 & 1,31 \\
\hline Case 3 & 1 & 1 & 1 & 78,6 & 56,9 & 1.38 & 1.38 \\
\hline Case 4 & 1 & 1 & 1 & 1436,9 & 2994,8 & 0,48 & 0,48 \\
\hline
\end{tabular}

* Given as milk formula

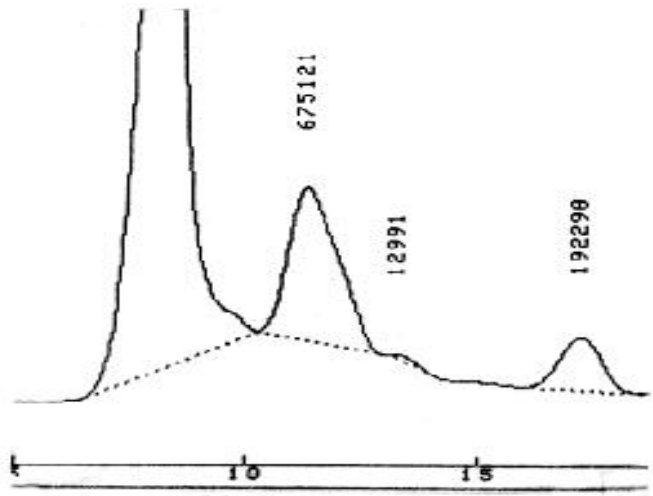

Figure 1. Chromatogram of lactose and lactulose in Case 1 Ingestion: $2 \mathrm{~g}$ lactose in $30 \mathrm{ml}$ milk and $1 \mathrm{~g}$ lactulose, IR of lactulose/lactose was 0,5.

Analysis was carried out by HPLC using cation axchange column Metachem ${ }^{\circledR}$ Metacarb Ca plus $(300 \mathrm{~mm}$ x 7,8 mm) as described in the methods.

The retention time of lactose was 11 minutes and lactulose was 13 minutes. (A. lactose, B. lactulose)

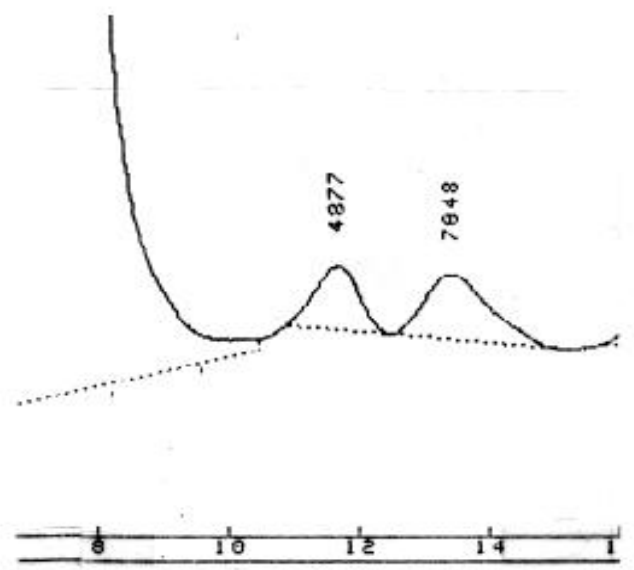

Figure 3. Chromatogram of lactose and lactulose in Case 3 Ingestion: $1 \mathrm{~g}$ lactose and $1 \mathrm{~g}$ lactulose in $10 \mathrm{ml}$ water, IR of lactulose/lactose was 1 .

Analysis was carried out by HPLC using cation axchange column Metachem ${ }^{\circledR}$ Metacarb Ca plus $(300 \mathrm{~mm} \times 7,8 \mathrm{~mm}$ ) as described in the methods.

The retention time of lactose was 11 minutes and lactulose was 13 minutes. (A. lactose, B. lactulose)



Figure 2. Chromatogram of lactose and lactulose in Case 2 Ingestion: 0,2 $\mathrm{g}$ lactose and $1 \mathrm{~g}$ lactulose in $10 \mathrm{ml}$ water, $\mathrm{IR}$ of lactulosellactose was 5.

Analysis was carried out by HPLC using cation axchange column Metachem ${ }^{\circledR}$ Metacarb Ca plus $(300 \mathrm{~mm}$ x 7,8 mm) as described in the methods.

The retention time of lactose was 11 minutes and lactulose was 13 minutes. (A. lactose, B. lactulose)

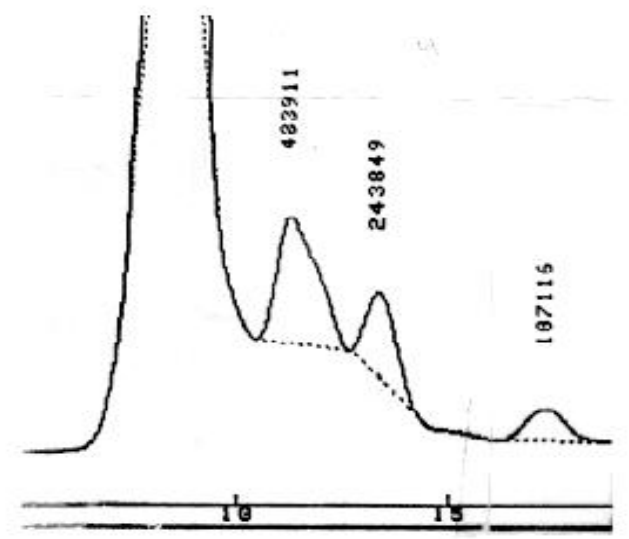

Figure 4. Chromatogram of lactose and lactulose in Case 4 Ingestion: $1 \mathrm{~g}$ lactose and $1 \mathrm{~g}$ lactulose in $10 \mathrm{ml}$ water, IR of lactulosellactose was 1.

Analysis was carried out by HPLC using cation axchange column Metachem ${ }^{\circledR}$ Metacarb Ca plus (300 mm x 7,8 mm) as described in the methods.

The retention time of lactose was 11 minutes and lactulose was 13 minutes. (A. lactose, B. lactulose) 


\section{DISCUSSION AND CONCLUSION}

Indirectly, determination of lactase activity can be done by measuring lactose amount excreted in urine. Intestinal absorption and permeation are being classified by the transportation method to go through intestinal membrane. Absorption mechanism happens by carrier mediated, while permeation enters passively. Absorption mechanism is relation with nutrition absorption, while permeation with barrier function. ${ }^{8}$ Even though the lactosuria level is inversely relation with gestation periode, intestinal capacity to absorb lactose is also influenced by intestinal permeability characteristic. Lactose in urine indicates high intestinal permeability and shows low lactase activity. ${ }^{9}$ Using disaccharide lactulose which does not metabolized in human intestinal offers way to study changes in lactase activity. Lactase activity is showed by the amount of lactose compared by lactulose in infant urine who ingests both disaccharides. Lactose and lactulose have the same molecular weight and diameter, 342 and $0,52 \mathrm{~nm}$ respectively. Lactose and lactulose are both experiencing the same permeation process into the intestinal membrane and fermentation in large intestine, except that lactulose does not experience hydrolysis in small intestine since human does not have a specific enzyme for lactulose hydrolysis. By giving and put through lactose and lactulose and then calculating the ratio of excretion in urine, factors that influence the amount of lactose can be neglected. The factors are intestinal permeability, enterocytes, lactose absorption variation, gastric emptying, intestinal transit time, and renal clearens. ${ }^{8,9}$

Lactulose and lactose which were given with milk formula and lactulose relatively less than lactose, such as in case 1 , were easy to feed. Urinary lactose and lactulose can be detected using HPLC (Figure 1), however needed milk analysis and lactulose might not be detected in more mature age.

When giving lactose which relatively less than lactulose such in case 2, might not be detected in more mature age. As shown in Figure 2, there was only a small amount of lactose detected by HPLC. Catassi et $a l .{ }^{13}$ also stated that giving sugar in 24 hours, as a steady state method, for infant aged 1 month could not detect sugar in urine.

Sugar solution, which ratio of lactulose and lactose was 1 , were given by single oral load method after 2 hours fasting. Lactose and lactulose were detected by
HPLC (Figure 3, 4). Method to give single oral load markers was also used by Goto et al., ${ }^{12}$ to estimate intestinal permeability. ${ }^{12}$

In conclusion, giving lactulose and lactose solution can be done with single dose after 2 hours fasting, followed by feeding cold water after 30 minutes. For the next 30 minutes, infant can drink normally. Urine was collected immediately after the sugar solution were given for 5 hours. The used of lactulose and lactose with ratio 1:1 can be performed, it is quite safe and easier to estimate the lactase activity, since the excretion ratio of lactulose and lactose compared to the ingestion ratio can be determine straight away.

Finally, as it has been mentioned before, lactase activity which was being calculated was the ratio of excretion and ingestion from lactulose and lactose. Therefore, the influence of intestinal permeability, mucosal condition, lactose absorption variation, and renal clearence can be neglected. The next study is to develop normal value of lactase activity in normal infants.

\section{ACKNOWLEDGMENT}

The authors like to thank to Mr. Rustam Paun, laboratory assistant from Department of Pharmacy, Faculty of Natural Science, University of Indonesia, for his help in laboratory work.

\section{REFERENCE}

1. Davenport HW. Intestinal digestion and absorption of carbohydrate. In: Davenport HW, ed. Physiology of the digestive tract. An introductory text. $5^{\text {th }}$ ed. Chicago: Year Book Medical Publishers; 1982.p.195-204.

2. Lebenthal E, Leung YK. Alternative pathways of digestion and absorption in the newborn. In: Lebenthal E, ed. Textbook of gastroenterology and nutrition in infancy. $2^{\text {nd }}$ ed. New York: Raven Press; 1989.p.3-7.

3. Gudman-Hoyer E. The clinical significance of disaccharide maldigestion. Am J Clin Nutr 1994;59 Suppl:735-41.

4. Rudloff S, Pohlentz G, Diekmann L, Egge H, Kuntz C. Urinary excretion of lactose and oligosaccharides in preterm infants fed human milk or infant formula. Acta paediatr 1996;85:598-603.

5. Sherwood L. The digestive system. In: Sherwood L, ed. Human physiology. From cells to systems. $3^{\text {rd }}$ ed. Belmont: Wadworth Publ. Co.; 1997.p.546-99.

6. Asp N-G. Nutritional classification and analysis of food carbohydrate. Am J Clin Nutr 1994;59 Suppl:679-81.

7. Levin RJ. Carbohydrate. In: Shils ME, Olson JA, Shike $\mathrm{M}$, Ross AC, eds. Modern nutrition in health and disease. $9^{\text {th }}$ ed. Baltimore: Williams \& Wilkins; 1999.p.49-65. 
8. Bjarnason I, Macpherson A, Hollander D. Intestinal permeability: an overview. Gastroenterology 1995; 108:1566-81.

9. Weaver LT, Laker MF, Nelson R. Neonatal intestinal lactase activity. Arch Dis Child 1986:61:896-9.

10. Antonowicz I, Lebenthal E. Developmental pattern of small intestinal enterokinase and disaccharidase activities in the human fetus. Gastroenterology 1977; 72:1299-303.

11. Weaver LT, Laker MF, Nelson R. Intestinal permeability in the newborn. Arch Dis Child 1984;59:236-41.

12. Goto K, Chew F, Torun B, Peerson JM, Brown KH. Epidemiology of altered intestinal permeability to lactulose and mannitol in Guatemalan infants. J Pediatr Gastroenterol Nutr 1999;28:282-90.

13. Catassi C, Bonucci A, Coppa GV, Carlucci A, Giorgi PL. Intestinal permeability changes during the first month : Effect of natural versus artificial feeding. J Pediatr Gastroenterol Nutr 1995;21:383-6.

14. Shulman RJ, Schanler RJ, Lau C, Heitkemper M, Ou CN, Smith EO. Early feeding, feeding tolerance, and lactase activity in preterm infants. J Pediatr 1998;133:645-9. 
